\title{
Indicators to assess biological diversity: Weyerhaeuser's coastal British Columbia forest project ${ }^{1}$
}

\author{
by Laurie Kremsater ${ }^{2}$, Fred Bunnell ${ }^{3}$, Dave Huggard ${ }^{4}$ and Glen Dunsworth ${ }^{5}$
}

\begin{abstract}
Adaptive management is a key component of a forest project being implemented across all of Weyerhaeuser's coastal forest tenures. This project uses two main tools to accomplish the British Columbia (BC) Coastal Group's ecological and socio-economic goals: variable retention (VR) harvesting and broad zoning of the land base. The adaptive management program was designed to examine the effectiveness of retention systems and zoning in maintaining those forest attributes necessary to sustain biological richness and essential ecosystem functions, such as nutrient transfer, energy flow, decomposition, and dispersal of seeds, spores, and animals. The program is grounded on three biological indicators evaluated in both operational and experimental contexts: 1) representation of habitat types in a relatively unmanaged state to ensure that little-known species are retained; 2) structure of stands and landscapes to ensure that key elements are present through time; and 3) indicator organisms to track whether retaining structures and patterns, while addressing representation, will maintain species and populations whose life needs are well understood. Representation of ecosystems in unmanaged conditions has been examined. Habitat structure is being assessed in VR blocks and in unmanaged blocks. Studies on several organisms (breeding birds, owls, gastropods, amphibians, bryophytes, lichen, squirrels, mycorrhizae, and carabid beetles) have been underway for various lengths of time. These studies collected baseline information to begin comparisons of the effectiveness of the various types of VR for maintaining biological richness. The current focus in the adaptive management program is refining the lists of specific elements to monitor and beginning to create tools to help extrapolate relationships and findings over large areas and long time frames, with the expectation of operational implementation in 2003. The first two years of pilot work are also being used to examine how the results will link to management practices to strengthen areas that most need improvement. This paper describes three indicators used in Weyerhaeuser's adaptive management program.
\end{abstract}

Key words: adaptive management, variable retention harvesting, indicators for monitoring forests

La gestion adaptée est un volet essentiel du projet forestier mis en oeuvre sur tout le territoire forestier aménagé par la Weyerhaeuser dans la région côtière de la Colombie-Britannique. Ce projet comprend deux principaux outils pour atteindre les objectifs écologiques et socio-économiques du B.C. Coastal Group : le régime de coupes à rétention variable et le zonage du territoire. Le programme de gestion adaptée a été conçu pour examiner l'efficacité des méthodes de récolte avec réserve (rétention) et du zonage pour la préservation des caractéristiques de la forêt essentielles au maintien de la richesse biologique et des fonctions essentielles de l'écosystème, comme le transfert des éléments nutritifs et de l'énergie, la décomposition et la dispersion des graines, des spores et des animaux. Le programme est axé sur trois indicateurs biologiques évalués dans des contextes opérationnel et expérimental : 1) représentation de types d'habitat relativement non aménagés pour assurer la rétention d'espèces peu connues; 2) structure des peuplements et des paysages pour assurer la présence d'éléments clés en tout temps; 3) organismes indicateurs pour surveiller si la rétention des structures et des patrons maintiendra les espèces et les populations dont les besoins vitaux sont bien compris, tout en veillant à la représentation. On a examiné la représentation d'écosystèmes à l'état non aménagé. La structure des habitats est évaluée dans des blocs aménagés avec des degrés variables de rétention et dans des blocs non aménagés. Plusieurs organismes (oiseaux nicheurs, hiboux, gastropodes, amphibiens, bryophytes, lichens, écureuils, mycorhizes et carabidés) font l'objet d'études depuis plus ou moins longtemps. Ces études ont fourni des données de base pour commencer à comparer l'efficacité de divers types de rétention variable pour le maintien de la richesse biologique. Une application opérationnelle étant prévue pour 2003, le programme de gestion adaptée concentre actuellement ses efforts sur l'amélioration des listes des éléments précis à surveiller et sur la création d'outils pour faciliter l'extrapolation des relations établies et des constatations sur de grandes surfaces et de longues périodes de temps. Les travaux pilotes des deux premières années servent également à examiner les liens qui pourront être faits entre les résultats et les pratiques d'aménagement afin de renforcer les domaines ayant le plus besoin d'améliorations. Dans ce rapport sont décrits trois indicateurs utilisés dans le programme de gestion adaptée de Weyerhaeuser.

Mots clés : gestion adaptée, coupes à retention variable

\section{Introduction}

Weyerhaeuser's "Forest Project" in the coastal forest of British Columbia (Fig. 1) attempts to improve environmental and economic performance by sustaining healthy, biologically

\footnotetext{
${ }^{1}$ Paper presented at the "Old-growth Forests in Canada: A Science Perspective" Conference, October 14-19, 2001, Sault Ste. Marie, ON.

2 Consultant, 28360 Starr Rd., Abbotsford, B.C. V4X 2C5. E-mail: 1krem@uniserve.com

${ }^{3}$ Centre for Applied Conservation Biology, UBC.

${ }^{4}$ Consultant, North Vancouver, BC.

${ }^{5}$ Weyerhaeuser Ltd.
}

diverse forests that ensure economic returns in the future. Tactics to attain these objectives include leaving habitat structure through variable retention (VR) harvesting and zoning the land base into areas having different kinds and intensities of forest practices (Table 1). In order of increasing levels of fibre extraction, there are three zones: Old growth, Habitat, and Timber. Variable retention harvesting is applied in the Timber and Habitat zones (see Beese et al. 2003).

Both the widespread use of VR and the approach to zoning are novel. Although well reasoned (Beese and Zielke 1998, Bunnell et al. 1998), all consequences of the new practices are unknown 


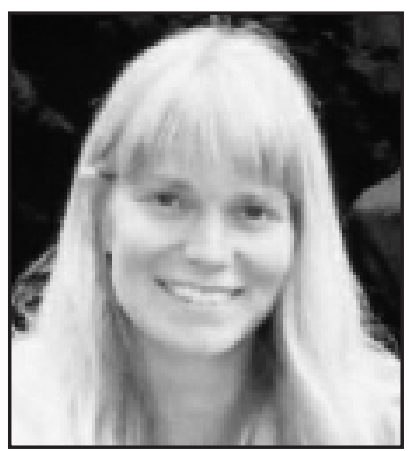

Laurie Kremsater

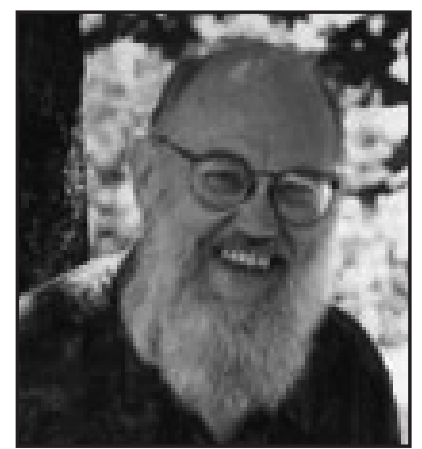

Fred Bunnell

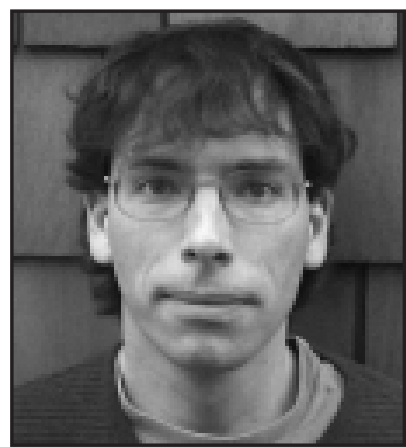

Dave Huggard

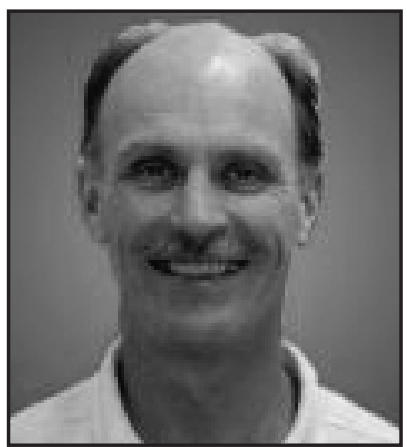

Glen Dunsworth and encumbered by uncertainties. Weyerhaeuser BC is committed to refining and improving the new practices through a program of adaptive management-a formal process for continually improving management practices by learning from outcomes of operational programs.

This paper describes the three indicators of biological diversity $^{6}$ that Weyerhaeuser is using to assess success in sustaining biological diversity. Components of these indicators are monitored in the Adaptive Management Program and results are used to address questions including: how does VR contribute to achieving the goal of maintaining biological richness? which practices are best (VR in patches, as dispersed cover, or in combination)? what edge effects are created by VR? what are the risks and values of stewardship zone locations? Indicators will be monitored in operational blocks and in experimental settings (see Beese et al. 2003). Information gained from monitoring the indicators in operational trials and during experimental research will be used to compare types of VR, examine trends over time, compare with targets, such as unmanaged benchmarks, and develop predictive tools to project and assess combinations of treatments over large spatial and temporal scales.

The monitoring program is in the development stage and is expected to be fully designed and implemented by 2003. Pilot projects are underway to assess (practicality, variability, required samples for adequate power, costs, etc.) which components of each indicator will be monitored over the long term. Pilot project reports are available from Weyerhaeuser, as is the framework document $(\mathrm{AMF})^{7}$ that sets out the plans for the adaptive management program. As well as describing the indicators in more detail, the framework document sets out the planned comparisons (operational and experimental designs) and potential modelling approaches, and outlines how results will be used to guide management. Here we offer a broad overview of the indicators selected to focus the monitoring program.

Indicator 1: Ecologically distinct habitat types are represented in a relatively unmanaged state across Weyerhaeuser BC's coastal tenure to maintain lesser known species and ecological functions.

\footnotetext{
${ }^{6}$ This paper summarizes information found in documents prepared by the Adaptive Management Working Group of Weyerhaeuser's Forest Project, collectively referred to in the text as AMF - Adaptive Management Framework.

${ }^{6}$ Bunnell, F.L., Dunsworth, G., Huggard, D.J., and Kremsater, L.L. (compilers). Adaptive Management Framework: Learning to Sustain Biological Diversiy on Weyerhaeuser's Coastal Tenure (in prep.).
}

Indicator 2: The amount, distribution, and heterogeneity of habitat and landscape elements important to sustain biological diversity are maintained over time.

Indicator 3: Productive populations of species are well distributed throughout Weyerhaeuser BC's coastal tenure over the long term.

Each indicator is intended to assess different components of success in maintaining biological diversity.

Indicator 1 is primarily intended to ensure that little-known species and ecological functions, that may not be assessed by Indicators 2 and 3, are sustained. It also serves to identify unmanaged "benchmarks."

Indicator 2 complements Indicator 1 by evaluating habitat requirements of many species and projecting consequences of changes in those requirements through time.

Indicator 3 is intended to assess whether species present on Weyerhaeuser BC's coastal tenure are likely to continue as welldistributed, productive populations. It serves as a test of the more "catch-all" approaches of Indicators 1 and 2.

The three major indicators interact. For example, the distribution of ecologically distinct habitat types (Indicator 1) within the three broad zones (old growth, habitat, and timber) determines how much of each habitat type is in the non-harvested land base, thus the kinds of habitat provision (Indicator 2) required in the Timber zone to ensure success. Indicator 1 may suggest areas where restoration should be implemented. Conversely, good habitat quality in the Timber zone may make specifics of the zoning less critical. Assessment of each of the three major indicators must proceed in parallel, because findings for each indicator will inform the others. Thus, their numerical order implies no primacy of effect. Instead, the order represents increasing refinement with increasing emphasis on individual forest attributes or species.

For each indicator, we address the rationale, features to monitor, and feedback to management.

\section{Indicator 1: Representation}

This is coarsest filter employed during monitoring within Weyerhaeuser's adaptive management program and it ensures that ecologically distinct habitat types are represented across Weyerhaeuser's coastal BC tenure, in order to maintain lesser known species and ecological functions.

\section{Rationale}

Many species, especially those for which knowledge is minimal or lacking, are best accommodated by ensuring that 


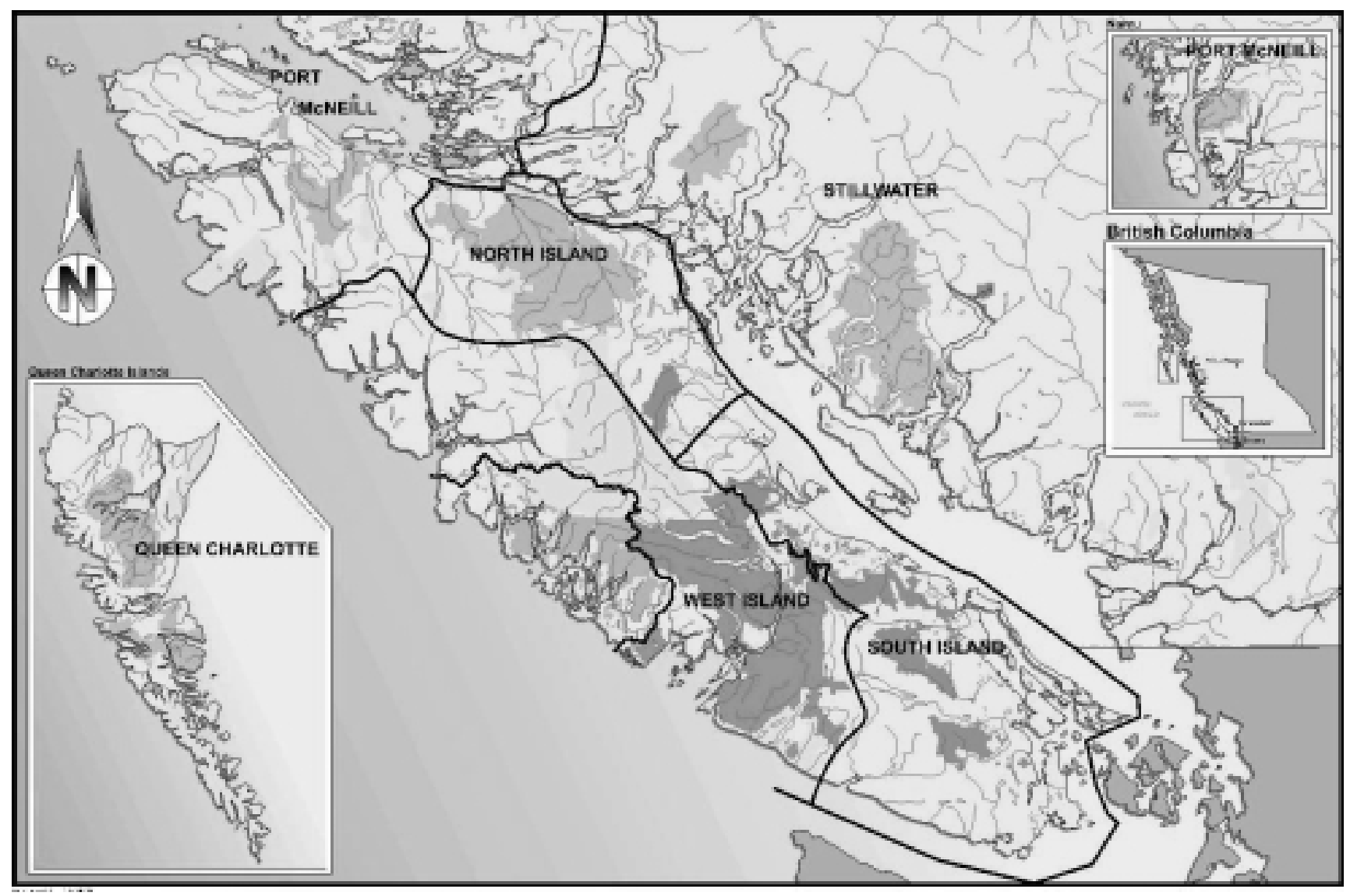

Fig. 1. Weyerhaeuser's tenures in coastal British Columbia, home of the Forest Project and its adaptive management program.

some portion of each distinct habitat type is represented in a relatively unmanaged state. Unmanaged areas provide a precautionary buffer intended to sustain poorly known species and processes within Weyerhaeuser's coastal tenure. They also are places where natural disturbances can occur that would otherwise be suppressed or reduced. Although some aspects of natural disturbance can be mimicked in managed stands, other aspects cannot (e.g., large patches of burned snags). Many organisms benefit from or rely on such features of natural disturbance (Lehmkuhl and Ruggiero 1991). A further function of unmanaged areas is to provide an ecological baseline against which the effects of human activities can be compared (Arcese and Sinclair 1997). Benchmarks are especially critical in the long-term monitoring required for adaptive management in forestry.

Managed forested land bases in BC typically have 20-50\% or more of the forest in an unmanaged state. This includes: 1) areas that are not harvested or harvested only lightly because of concerns other than conserving biological diversity (e.g., inoperable areas, visual quality, watershed protection); and 2) areas intentionally set aside to protect biological diversity (e.g., old-growth zones, riparian buffers, reserve patches within blocks). The unmanaged proportion of the land base most often exceeds protected areas objectives of most jurisdictions (typically $12 \%$, following the Brundtland commission), and is comparable to many recommendations derived from principles of conservation biology (e.g., 33-50\%, Sætersdal and Birks 1993, Stokland 1997, Soulé and Sanjayen 1998).

The critical question for monitoring is whether most or all ecosystem types are represented in the unmanaged land base, and, secondarily, whether the size, shape, age, and spatial distributions of unmanaged areas are appropriate (see below).

\section{What to monitor}

To assess levels of representation, we evaluate areas that are in the currently unmanaged or very lightly managed part of the land base to determine:

- the amount of the forest currently in reserves or lightly managed areas;

- the ecosystem types comprising those areas;

- the patch size and geographic distribution of those areas; and

- the amount of "forest interior."

Approaches to monitoring these aspects of representation through time can be found in the AMF.

\section{Feedback to management}

Monitoring of Indicator 1 documents which ecosystem types are absent from or poorly represented in the unmanaged land base, and which are represented by only small or poorly distributed areas or a poor age-class distribution. Monitoring also indicates which ecosystems are relatively over-represented. This information can help management decisions by: 
Table 1. Stewardship zones and their attributes

\begin{tabular}{|c|c|c|c|c|}
\hline Stewardship zone & Description & $\begin{array}{l}\text { Minimum level of } \\
\text { stand retention }\end{array}$ & $\begin{array}{l}\text { Landscape available } \\
\text { for harvest }\end{array}$ & $\begin{array}{c}\text { Suitable } \\
\text { silvicultural systems } \\
\end{array}$ \\
\hline Old Growth & $\begin{array}{l}\text { Covers about } 10 \% \text { of the tenure. Two thirds } \\
\text { of the zone reserved from harvest. }\end{array}$ & $20 \%$ & $33 \%$ & $\begin{array}{l}\text {-group selection } \\
\text {-irregular } \\
\text {-shelterwood }\end{array}$ \\
\hline Habitat & $\begin{array}{l}\text { Covers about } 25 \% \text { of the tenure. Amount of } \\
\text { area in retention and reserves can be modified } \\
\text { to meet specific needs }\end{array}$ & $15 \%$ & $70 \%$ & -full range \\
\hline Timber & $\begin{array}{l}\text { Covers about } 65 \% \text { of the tenure under variable } \\
\text { retention. Focus of this zone is timber production } \\
\text { without losing species from large geographic areas. }\end{array}$ & $\begin{array}{l}-10 \% \text { for group retention } \\
-5 \% \text { for dispersed retention }\end{array}$ & $80 \%$ & $\begin{array}{l}\text {-group retention } \\
\text {-dispersed retention } \\
\text {-shelterwood }\end{array}$ \\
\hline
\end{tabular}

1. Helping decide the amount and location of Old Growth and Habitat stewardship zones or old-growth management areas. Flexibility in the location, extent, or practices within these zones will allow under-represented types to be targeted.

2. Evaluating non-biodiversity reserves. Many areas are left unmanaged for reasons other than sustaining biological diversity (e.g., deer winter ranges, soil or slope stability). Knowing what ecosystem types are, or are not, well represented in such reserves can help evaluate their locations and extent (e.g., it may be possible to locate candidate deer winter ranges so they contribute to both their original objective and to ecosystem representation).

3. Increasing representation through retention patches and retention levels within VR settings. Patches of habitat retained can likely serve as representative unmanaged forest for many small organisms (studies under indicator 3 will evaluate how useful they are for a variety of organisms). Ecosystem types that are poorly represented overall can serve as "biological control points" for locating within-block reserves. Higher retention levels can be favoured in poorly represented ecosystems.

4. Focusing finer-scale monitoring. The potential ecological benefits of VR are greatest within ecosystem types that are poorly represented in the unmanaged forest. These ecosystem types should, therefore, be a focus of the monitoring of habitat (medium filter) and specific organisms (fine filter).

\section{Indicator 2: Habitat and Landscape Structures}

Indicator 2 is the intermediate filter and addresses kinds, amounts, and heterogeneity of forest structures necessary to sustain organisms in managed stands and landscapes. Similar to Indicator 1, maintaining diverse habitat structures is intended to provide for a broad range of organisms, including many that are poorly known.

\section{Rationale}

Much of the approach to describing habitat elements at the stand level derives from the comprehensive review of wildlife habitat by Thomas (1979), which effectively institutionalized a set of habitat elements as the "canon" for describing wildlife habitat. The elements have since been measured in many studies of wildlife habitat, and form the basis for most biodiversity monitoring in the Pacific Northwest (e.g., Mulder et al. 1999). This standard set of habitat elements includes large live trees, snags, downed wood or coarse woody debris (CWD), canopy cover, shrub cover, and ground cover layers. Bunnell et al. (1999) reviewed attributes of some of these elements (e.g., size and decay state of snags) that have been shown to influence vertebrate use of habitat in the Pacific Northwest. Much of the ecological rationale for implementing VR on Weyerhaeuser's coastal BC tenure was based on retention of these habitat elements.

Monitoring these standard habitat elements has some obvious advantages: 1) we can relate a large literature base on stand-level habitat relationships to the results of our monitoring; 2) we can compare our results to other similar monitoring in the region; and 3) at least some of the parameters needed to project these elements through time have been measured by other studies (e.g., Harmon et al. 1986 and Daniels et al. 1997 for snags).

However, there are perils in adopting a standard set of habitat elements, developed for vertebrates, when we wish to reduce the negative effects of forest harvesting on the full spectrum of organisms. Reviewing natural history studies of nonvertebrate groups may help to identify additional structures of importance, and avoid the circularity of using a standard set of habitat elements to define habitat, or at least help to test the adequacy of those elements. Using the standard set of habitat elements can also enforce a reductionist, point-scale view of habitat: the elements themselves are considered as separate, discrete units. For many organisms, "habitat" is larger than the individual habitat element, and smaller than a typical stand. Therefore, we also examine indices of structural complexity or horizontal patchiness. Some organisms respond to habitat at broader scales than stands, thus we include attributes of landscapes as important habitat characteristics to monitor.

\section{What to monitor}

We consider five broad groups of variables: 1) the standard set of habitat elements and their attributes, 2) more integrative habitat variables describing habitat structure, 3 ) processes critical to making long-term habitat projections, 4) broad-scale summary variables, and 5) indicator or idealized organisms.

\section{The standard set of habitat elements}

Much has been written on these (e.g., Thomas 1979, Brown 1985, Bunnell et al. 1999), so below we simply list examples of the kinds of attributes we are measuring for each of the standard habitat attributes.

Live trees: species, diameter at breast height (dbh), height, height of live crown (used for vertical structure), trunk breaks, and visible disease or pathogens. Live trees define forest habitat 
and are important both directly and as the source of dead wood elements. Important attributes of live trees include some large trees, hardwood or deciduous components, advanced regeneration, and a diversity of sizes and conditions.

Snags (standing dead trees): species, dbh, height, decay class, and top breakage. Ecological reasons for maintaining snags in forests are well documented. Important attributes of snags include some large and tall snags, but also a range of species, size classes, and conditions.

Coarse woody debris: species, size, decay class. The use of CWD by rodents, small carnivores, amphibians, and invertebrates is well documented (AMF). It is also critical for other taxa, both directly as substrate, and through its influence on ecosystem processes, such as nutrient cycling, water retention, slope stability, stream morphology, microclimate effects and contributions to plant-fungus interactions. Coarse woody debris is the most likely of all habitat elements to appear abundant immediately after harvest, but become limiting later in the rotation. Therefore, projection models are particularly important for assessing CWD.

Canopy: cover, depth, and composition. Characteristics of canopy cover include area of deep crowns, area of dense patches, and species composition of canopy.

Shrubs: cover and composition. In managed stands, shrubs may be reduced by vegetation management in early seral stages, or prevented from re-entering later stages by dense stocking and low mortality of the crop trees. Attributes of shrubs that merit monitoring include dense, tall shrub cover and representative species composition.

Ground cover layers: cover, height/depth and composition of forb, moss/lichen, litter/duff and inorganic layers. Ground cover layers are directly affected by forest practices, especially site preparation, but over time are probably more influenced by changes in canopy and understorey trees and shrubs. These layers have strong effects on many species of small mammals, invertebrates, non-vascular plants, lichens, and fungi on the forest floor and in forest soils, but little is known about what these taxa require. Hence, ground cover layers receive less emphasis in our monitoring. Monitoring of forbs, bryophytes, and ground lichens as individual species is addressed in Indicator 3 (species). Here we focus on the structural attributes of these species when grouped as the ground cover. Priority attributes include dense patches of forb cover, diversity of forb cover, intact areas of moss or lichen cover, and depth and development of the litter layer.

\section{Integrative habitat variables (habitat structures)}

The preceding habitat features are separate, individual elements. Their relations with organisms are most likely expressed through a critical single resource (e.g., large hollow snags for swifts) or in a habitat model combined with other elements (e.g., multiple regression models). A complementary approach to stand-level habitat monitoring is to identify and monitor more integrative habitat structures. These structures may be less directly related to the needs of particular species, but help to maintain broader communities, or a greater richness of species.
Some structural measures suggested below can be derived by combining several measured elements in a habitat plot, others come from combining measurements from several plots within a stand, and some require additional sampling or different survey methods.

Vertical structural diversity. Vertical structural diversity was one of the first variables used to explain differences in diversity of forest bird assemblages (MacArthur and MacArthur 1961). The vegetation layers of interest include forbs and shrubs, as well as trees.

Horizontal patchiness of canopy trees. Variation in the size and density of trees is a feature of older natural forests that is reduced in managed stands. Canopy gaps, dense patches of trees, and internal soft edges are often reduced. Monitoring of horizontal patchiness can use summary measures of spatial variability derived from multiple plots within a stand, or new measures from broader-scale surveys or from aerial photos.

Horizontal patchiness of other elements. Horizontal patchiness of canopy is important because canopy trees directly influence other aspects of the forest. However, the same argument that heterogeneity promotes richness applies equally to other habitat elements. Thus, heterogeneity in CWD volumes, shrub cover, or other habitat elements within and between stands will help ensure suitable conditions for the diverse organisms using these elements in different ways.

Special ecosystem types within stands. Natural history observations of various taxonomic groups suggest that particular site types within forested areas greatly enhance the overall diversity of the surrounding stand. These sites include small wetlands, headwater streams, seepage areas, small landslide areas, etc. The contribution to diversity derives not just from the site itself, but also from its interaction with the adjacent forest. Monitoring can indicate the extent to which such special sites are retained with intact, or partially intact, surrounding forest cover.

Representation of site series within stands. In BC, site series (combinations of site moisture and productivity indicated by unique assemblages of indicator plants) constitute a well-recognized summary variable, indicating differences in forest growth rates, successional pathways, and vegetation communities (Pojar et al. 1987). Vertebrates often show differences in abundance or use of different groups of site series, but no restriction to a particular series. Other taxa (fungi, lichens, bryophytes) appear more restricted to particular site series. The degree of within-stand (finer than measured in Indicator 1) representation of site series in retained areas will be monitored for Indicator 2 .

\section{Process variables for long-term habitat projections}

To assess likely consequences of forest practices, future levels of habitat elements and structures in managed stands have to be predicted. Process variables are critical to any habitat projection model. Most of these variables also influence the amount of wood harvestable from trees (economic values) and nutrient cycling or long-term site productivity. Some parameters required by projection models include: 
- growth of the regenerating stand;

- mortality of retained and regenerating trees;

- fall and decay rates of snags, decay rates of CWD;

- shrub, forb and moss/lichen growth, succession, and interaction with trees; and

- decay rates and input to litter cover.

\section{Landscape structures}

Landscape is used here to include any features created by two or more relatively homogeneous stands, or measurements made over an area larger than the typical stand. The problem with choosing landscape variables to monitor as a medium to coarse filter for biological diversity is that most available variables are:

- organism specific (e.g., "percent interior," Murcia 1995; or "connectivity," Beier and Noss 1998);

- not related to any organism in empirical studies (many possibilities);

- lacking intuitive natural history basis (e.g., "fractal dimension"); or

- unsupported by either empirical studies or intuitive natural history (e.g., "contagion").

Empirical studies of landscape-level effects commonly fail to account for the fact that organisms are associated with particular habitat types and these habitat types are not located randomly. For example, a species that prefers recent cutblocks will tend to be found in landscapes with higher percentages of young stands, more edge, greater contrast, lower fractal dimension, etc., simply because each of these features is associated with more frequently managed or disturbed landscapes. The association will occur even if these other landscape variables are irrelevant to the species.

The biological relevance of landscape variables is further reduced in forested landscapes where succession occurs after harvest. A successional gradient obscures the concept of stand "type" required for GIS type analyses. Variable retention deliberately obscures stand types even further by reducing the distinctness of recently cut and older stands for many organisms.

Given the ample opportunity for confusion, it seems unlikely that we can find a set of variables that reliably indicates how well a dynamic forest landscape, managed with VR, is sustaining the full range of organisms. Instead, we suggest a combination of two approaches for monitoring landscapes:

1) tracking a few simple variables that have been shown to have relevance to many organisms, such as distribution of patch age and size classes, edge-contrast length and interior, and road densities and distribution (see AMF for details on monitoring); and

2) using spatial models for a range of indicator taxa (real or idealized (see next section)) to put together the dynamic, organism-specific aspects of landscapes. This approach requires estimates of many parameters, which will have to come from initial best guesses, literature sources, and field work that contributes to assessing Indicator 3.

\section{Indicator organisms (idealized) for landscape evaluation}

To interpret landscape structure, we need to know species' responses to stand-level practices, the time to "recovery" of suitable habitat in managed stands, organisms' ability to move through non-suitable habitat, and their movement distances. There are, however, thousands of species, each responding differently.
Our approach to interpreting landscape structure will be to use a set of real (discussed in Indicator 3) or idealized indicator organisms that represent a range of responses. The choice of real and idealized indicator organisms must be closely linked to our understanding of natural history. Generally, idealized indicator organisms will be chosen to cover a range of several important variables, in combinations that reflect real organisms. To assist landscape evaluation these variables could include:

- effectiveness of VR in maintaining habitat quality (habitat defined for an idealized species);

- "recovery time" of disturbed habitat;

- dispersal distances and rates;

- effects of VR and stand age on dispersal distances; and

- utility of different types of unmanaged, non-harvestable stands for habitat or dispersal.

All possible combinations of different values of these variables will not be needed as indices. Some combinations will represent species that are of no conservation concern because they will tolerate any possible managed landscape. Other combinations will not correspond to any known organism. The focus is on representing realistic organisms that are potentially sensitive to possible landscape management options. The benefit of using "idealized" organisms is that they can indicate landscape structures without being tied to the particular natural history traits of real organisms (e.g., their particular food types, predator behaviours, etc.)

\section{Feedback to management}

As with other portions of the adaptive management program, monitoring habitat structures (Indicator 2) feeds back to management by identifying the weakest aspects of practices, suggesting better alternatives, and monitoring long-term improvement. The connections between Indicator 2 and management are the most direct of all indicators because elements of habitat are directly changed by forest practices. The information gathered by monitoring Indicator 2 can help management decisions in three ways.

Selecting among and refining forest practices. Although VR is the major practice, Weyerhaeuser employs a broad range of silvicultural practices. Within VR, the range in amounts and quality of habitat elements is wide. When the program was initiated, reasoned guesses were made about the kinds of habitat that would be produced and how some forest-dwelling organisms would respond. Monitoring Indicator 2 documents changes in habitat features and structures resulting from VR practices. Combined with Indicator 3, it reveals the likely success in sustaining forest-dwelling organisms. Together, they help to guide managers in the selection of practices and help reveal how those practices might be improved if they are not meeting the needs of some organisms.

Guiding forest planning. Forest practices are applied over large areas producing particular mixtures of landscape structures. How these structures are distributed through time and space is a product of forest planning and natural succession. Although potential consequences to habitat of inappropriate planning appear to be large, little is known about desired landscape structure in managed forests. Monitoring Indicator 2 should at least reveal undesirable trends and suggest how these can be avoided. 
Assessing long-term trends. Because trees grow relatively slowly, consequences of particular forest planning and practice may not be evident for decades. An important aspect of the Indicator 2 monitoring is to expose undesirable trends early by projecting long-term consequences. Equally, the ability to project consequences of particular sets of planning and practice should expose the possibilities of improvement. Both capabilities can help guide management decisions. Creating models (with appropriate calibration and testing) to project changes through time in stand and landscape features is a critical step in applying this monitoring.

\section{Indicator 3: Species}

Indicator 3 is the fine-filter measure of the criterion for maintaining biological richness. Monitoring the responses of particular species to forest structure and pattern is useful for species whose requirements we know relatively well, or for which we can track relative trends over time.

\section{Rationale}

Monitoring species assesses whether habitat types, stand structures, and landscape patterns created by VR and zoning result in persistent populations of focal species. It can do that only for species that are readily sampled and relatively well known. Indicators 1 and 2 will encompass most of the species present, and Indicator 3 aims to identify species that do not fall within Indicators 1 or 2 . To assess the status of key species, Indicator 3 contains three separate parts: 1) the presence of productive populations, 2) the distribution of populations, and 3) long-term trends.

Conservation of species is seen as the ultimate indicator of success or failure, particularly by the public. Although the scientific rationale and tactics for sustaining biological richness are more directly evident in Indicators 1 and 2, the continuation of species is the most easily understood outcome.

Two key points guide the monitoring of species. First, monitoring all species is infeasible. Second, focus on individual species can seriously detract from the goal of sustaining species richness, by allocating resources to a minute portion of the species present. An alternative that examines key species representing a range of habitat requirements is most useful.

\section{What to monitor}

Selection of species for monitoring can be guided by three broad features: sensitivity to forest practices, ease of monitoring, and usefulness of information for guiding management. Some species are relatively insensitive to changes in forest cover or structure, so they provide no indication of the kinds of changes that might impact other species dramatically. Some large groups of species (as among the invertebrates) are poorly known in terms of taxonomy and natural history. They can be neither sampled nor interpreted effectively. Some species that are sensitive to forest practices and can be sampled are equally, or more, sensitive to other influences, so that information cannot be used to guide management (e.g., salmon and oceanic factors).

To ensure that most life forms were considered, we evaluated six broad groups of forest-dwelling organisms: 1) vascular plants, 2) bryophytes, 3) lichens, 4) macro-fungi, 5) terrestrial vertebrates, and 6) invertebrates. We have assumed that microscopic organisms are being monitored indirectly by monitor- ing other aspects of ecosystems (e.g., representation, tree and plant growth, organisms higher in the food chains). The initial step was selecting species or species groups that were both sensitive to forest practices and practicable to monitor (e.g., accessible to sampling and informative). We assessed how costly it would be to acquire information with the requisite precision and accuracy using pilot studies, and weighed that against the relevance of the information to adaptive management. Relevance to adaptive management included sensitivity to management options, ability to guide changes in practice, and the degree to which the species might represent other species or ecosystem functions. An effective group includes species representing a range of mobility, range of turnover rates, specialists and generalists, different trophic levels, large and small home ranges, species with close associations with a range of habitat elements, and some that are known less well. The AMF provides a rationale (based on literature review) for specific taxa; here we summarize key points.

\section{Vascular plants}

As well as monitoring broad groups of plants during habitat structure surveys (Indicator 2), we will choose representatives from the groups in Table 2 as focal vascular plant species. The final list will consider other organisms, and include a mix of characteristics, among them: pioneer to climax, good to poor dispersers, long versus short persistence (perennial long-lived versus annual), and species showing affinities with particular stand attributes that are changed by forest practices. Monitoring will begin in the Timber Zone and experimental sites (including benchmarks). The assessment of representation under Indicator 1 will guide monitoring for vascular plants. Underrepresented habitat types will be the focus when evaluating whether managed blocks are maintaining these organisms.

In intensively managed areas, major issues potentially affecting vascular plants are reduction of old growth, limited amounts of forest-interior habitat, and effects of harvesting, site preparation, and stand tending on species in the matrix. Few vascular plants appear limited to old-growth or forest-interior habitat. Those that may be (Groups C, D, and possibly B of Table 2) will serve as focal species during habitat structure surveys of $\mathrm{VR}$, in both patches and openings.

As a group, vascular plants are feasible to monitor and methods are well established. The larger question is the usefulness of the information. The most useful information will come from:

- tracking potential expansion of the range and abundance or exotics;

- changes in range of less common plants;

- effects of VR for species assumed to be dependent on old growth or forest interior; and

- monitoring plants in the managed matrix.

\section{Fungi}

Because they are difficult to detect, we do not consider microfungi or hypogeous fungi as potential species to monitor. Nor do we include non-mycorrhizal epigeous fungi due to difficulties in sampling. The adaptive management program focuses only on evaluating effects of VR on mycorrhizal and epixylic macrofungi.

For mycorrhizal fungi, the sampling design will consider two key variables: edge effects and levels of downed wood reten- 


\begin{tabular}{|c|c|c|}
\hline & Common Name & Latin \\
\hline $\begin{array}{l}\text { A. Selected vascular plants frequently } \\
\text { associated with canopy cover (preferring } \\
\text { a degree of shade and moist conditions) }\end{array}$ & $\begin{array}{l}\text { Devil's club } \\
\text { False Solomon's seal } \\
\text { Star-flowered false Solomon's seal } \\
\text { Clasping twisted-stalk } \\
\text { Rosy twisted-stalk } \\
\text { Hooker's fairy bells } \\
\text { Smith's fairybells } \\
\text { Western trillium } \\
\text { Pink fawn lily } \\
\text { Single delight } \\
\text { One-sided wintergreen } \\
\text { Pink wintergreen, white-veined wintergreen } \\
\text { Fairy slipper } \\
\text { Phantom orchid } \\
\text { Long-bracted frog orchid } \\
\text { Redwood sorrel } \\
\text { Bunchberry }\end{array}$ & $\begin{array}{l}\text { Oplopanax horridus } \\
\text { Smilacina racemosa (not QCI) } \\
\text { Smilacina stellata (not QCI) } \\
\text { Streptopus amplexifolius } \\
\text { Streptopus roseus } \\
\text { Disporum hookeri (not QCI) } \\
\text { Disporum smithii (not QCI) } \\
\text { Trillium ovatum (not QCI) } \\
\text { Erythronium revolutum (not QCI) } \\
\text { Moneses uniflora } \\
\text { Orthilia secunda } \\
\text { Pyrola spp. (picta and asarifolia (not QCI) } \\
\text { Viola } \text { spp. (glabella, howellii, lancolata, } \\
\quad \text { sempervirens) (sempervirens not QCI) } \\
\text { Calypso bulbosa dry to moist mossy forests } \\
\text { Cephalanthera austinae moist to mesic forest } \\
\text { (not QCI) } \\
\text { Coeloglossum viride moist to wet forests } \\
\text { Oxalis oregana } \\
\text { Cornus canadensis }\end{array}$ \\
\hline $\begin{array}{l}\text { B. Selected ferns and allies needing moist } \\
\text { condition for establishment }\end{array}$ & $\begin{array}{l}\text { Deer fern } \\
\text { Giant chain fern } \\
\text { Lady fern } \\
\text { Spiny wood fern } \\
\text { Sword fern } \\
\text { Oak fern } \\
\text { Narrow beech fern } \\
\text { Maidenhair fern }\end{array}$ & $\begin{array}{l}\text { Blechnum spicant } \\
\text { Woodardia fimbriata } \\
\text { Athyrium felix-femmina } \\
\text { Dryopteris expansa } \\
\text { Polystichum munitum } \\
\text { Gymnocarpium dryopteris } \\
\text { Thelypteris phegopteris } \\
\text { Adiantum pedatum }\end{array}$ \\
\hline
\end{tabular}

C. Selected vascular plants associated with downed wood or rich humus
D. Selected vascular plants that literature indicates may be associated with old forests

E. Selected vascular plants that literature indicates may be associated with forest interior

F. Selected exotic species that may be useful to track
Indianpipe

Pinesap

Candystick

Gnome plant

Pinedrops

Huckleberry

Menzies' pipsissewa

Prince's pine

Fairy slipper

Western corral root

Spotted coral-root

Striped coral-root

Rattlesnake plantain

Small twisted stalk

The saprophytes listed under downed wood (B above)

Rattlesnake plantain

Trillium

Western yew

Scotch broom

Himilayan blackberry

Wall lettuce

Common burdock
Monotropa uniflora (not QCI)

Hypopitys monotropa

Allotropa virgata (not QCI)

Hemitomes congestum (not QCI)

Pterospora andromedea (not QCI)

Vacinnium parvifolium

Chimaphila menziesii (not QCI)

Chimaphila umbellata (not QCI)

Calypso bulbosa

Corallorhiza mertensiana

Corallorhiza maculata

Corallorhiza striata (not QCI)

Goodyera oblongifolia

Streptopus streptopoides

Goodyera oblongifolia

Trillium ovatum (not QCI)

Taxus brevifolia

Cytisus scoparius

Rubus discolor

Lactuca muralis

Arctium minus tion. Monitoring of mycorrhizal species involves directly monitoring the fungi by root-tip samples and possibly sporocarp counts. Because moisture limits sporocarp production, sporocarp abundance is not necessarily correlated with below-ground abundance. For epixylic saprophtytic and parasitic fungi, the monitoring program will address whether fungal richness and abundance differs in VR patches from areas of older forest and whether these patches act as sources for fungal recolonization of younger forests. The variety of epixylic fungi in patches near edges can be compared to areas of larger forest and tracked over time to examine the role of old-forest patches in the "lifeboating" of fungi into older second growth.

Evaluating effects of edges on mycorrhizal distribution can help design the best patterns of VR to promote mycorrhizal persistence in young forests. Relationships between downed wood levels and mycorrhizae composition and abundance can help guide amounts of downed wood retained in patches and in cutover areas. Relationships of epixylic fungal composition 
and abundance to patch size and stand age will indicate whether further attention to epixylic fungi is warranted in the Timber zone.

\section{Bryophytes}

Monitoring of bryophytes will focus on how available substrate and microclimatic regimes influence persistence and rates of colonization after canopy removal. There is little evidence to suggest that species disappear quickly as canopy is removed, and evaluating rates of colonization is necessarily long term. Initial monitoring will focus on persistence of bryophytes in cutover areas of various ages, and examining stands of a variety of ages with similar amounts of downed wood). To evaluate potential influences of microclimate, bryophyte surveys will examine bryophytes in openings, in edges, and in patch interiors. Assessment of representation under Indicator 1 may help to focus the choice of bryophyte species, by recording underrepresented ecosystems. A few rare bryophytes have been found on wood or humus and so may be affected by forestry practices. If these mosses are encountered during surveys, they will be recorded and impacts of disturbance tracked over time. Rare mosses and liverworts, as any rare species, are infrequently encountered and so can only be included in the monitoring program in an opportunistic sense. If key areas of rare mosses are located, then more focused effort can be considered.

Bryophytes are one group of species that can help to assess whether sufficient downed wood in a range of decay states is likely to be retained by VR. They also provide insight into how well small patches, or even dispersed retention, sustain small, relatively immobile organisms that can be prone to desiccation. Given the moist coastal environment, bryophytes may benefit significantly from relatively small amounts of retention, but that has not been evaluated.

\section{Lichens}

Our review of lichen associations with their habitat indicates that some lichen groups are more amenable to monitoring than others, and also suggests some key variables in the design of a lichen monitoring project.

Lichens, particularly nitrogen-fixing lichens, appear to do best and are present in greater richness within older stands (Arsenault and Goward 2001). If these species cannot be retained in VR patches, they may become limited to the Old Growth zone or other larger tracts of unmanaged forest. If particular elevational belts are lacking in the unmanaged forests (Indicator 1), larger patches may be necessary to sustain lichens in the Timber zone. Monitoring will assess the persistence of lichens in remnant patches of different sizes and evaluate if lichens commonly associated with old forests begin to be established in second-growth forests. If monitoring reveals that VR patches provide lifeboats for lichens to recolonize second growth, then effective dispersal distances can also be investigated to indicate best arrangement of patches to facilitate maintenance and establishment of lichens in managed stands.

Pendant arboreal lichens are relatively easy to identify and easier to monitor than the more diverse non-pendant arboreal or epixylic lichens. Most epixylic lichens are difficult to identify and to monitor, so bryophytes may serve better to indicate the sustained provision of downed wood. Although it is possible that forest practices could have greater effects on some small, hard-to-identify lichens, monitoring pendant lichens is the most feasible source of information on the ability of VR patches to maintain and allow dispersal of species that require oldforest conditions. Lobaria species, although not pendant, are also readily identifiable and also will be monitored because of their apparent association with older forest and potential role in nitrogen fixation. Representatives from the rare lichens potentially present in the tenure can be included where identification is relatively easy.

\section{Invertebrates}

Some invertebrates are poor dispersers and so may be useful indicators of success (or lack thereof) of VR in mitigating negative edge effects and isolation effects. The most useful group of invertebrates to monitor and to examine edge and isolation may be terrestrial carabid beetles (Niemela et al. 1996). Some carabids are readily identifiable, but only a few species of Carabidae are likely seriously affected by logging (Okland et al. 1996). Specific carabids that appear useful indicators of old forest from pilot studies (AMF) include Scaphinotus angusticollis, Scaphinotus angulatus, Pterostichus crenicollis, and Zacotus matthewsii. In addition to Carabids, gastropods are also poor dispersers and may be useful to monitor. Specifically, the western thorn, pacific sideband, western flat whorl, toothless column, pygmy oregonian, robust lancetooth, and tightcoil species were more abundant in control areas and showed decreased abundance in logged areas (AMF). Prezio et al. (1999) indicated gastropods are often reduced by disturbance (e.g., timber harvesting, vegetation control), but noted that many authors have reported decreases to be temporary and, despite being relatively slow dispersers, recovery was rapid. Year-to-year variation in weather can have effects on gastropods of similar magnitude to effects of forest management.

Results of invertebrate surveys in VR patches of different sizes can help indicate patch sizes that would maintain many invertebrate assemblages. Studies of invertebrates in the matrix around VR patches and across forest edges can indicate edge effects, and if these studies are repeated at intervals as the matrix ages, they can examine dispersal from VR patches or surrounding forests into the matrix.

\section{Vertebrates}

An assessment of the usefulness of various vertebrate species, including species of concern is ongoing. Species of concern include those listed as red or blue by the provincial government, or listed by the Committee on the Status of Endangered Wildlife in Canada (COSEWIC), or species for which populations are on a downward trend but which have not yet reached listed status. Pilot studies are evaluating the usefulness of a range of vertebrates in the monitoring program, including red-tailed frogs, aquatic and terrestrial-breeding salamanders, songbirds, owls, and squirrels. We are attempting to include a range of vertebrates from smaller, less mobile ones, to species with very particular requirements (e.g., large snags or downed wood), to wideranging species. We remain focused on those vertebrates that are practical and cost-effective to monitor and whose response can inform management practice (AMF).

\section{Feedback to management}

Monitoring of Indicator 3 indicates occurrence, abundance, trends in populations, or changes in ranges for many species (or groups of species). For some species, links to habitat 


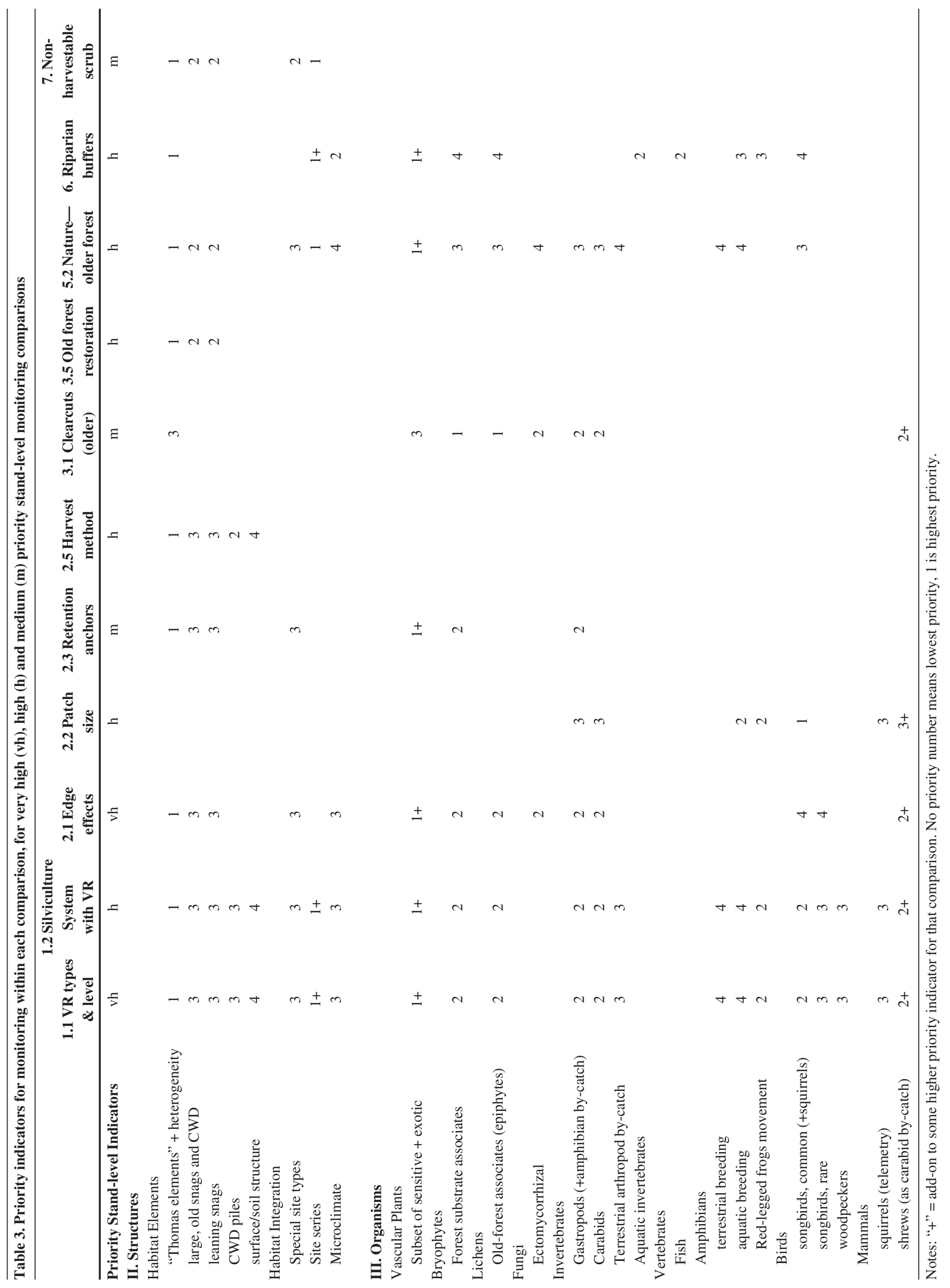


structures will be examined. Because these measures require different levels of effort, many more species will have occurrence information than will have information on population trend. Information on species can help management decisions in the following ways.

Information on occurrence. Presence or absence of species can be compared over time to examine reductions or expansions in species ranges. Large expansions in range of particular groups of species (e.g., exotics) may indicate areas needing closer examination to establish causes and potential management responses. Consistency or expansion in ranges of species commonly associated with older forests may indicate success of VR in providing habitat structures for species more typically associated with older forests than with harvested areas.

Trends in population. Trends in population can be useful over both the short and long term. When associations of species with particular habitat elements are known and species are not wide ranging, reasons can likely be deduced for reduction in species populations and steps undertaken to increase needed habitat elements. Even where associations with particular habitat elements are poorly known, pronounced, long-term trends (either upward or downward) should trigger closer scrutiny of potential causes.

Different groups of species are appropriate for examining different scales. Trends in some organisms (e.g., epiphytic mosses and lichens) can help determine if VR is providing suitable microclimatic conditions within patches or near edges. Trends in songbird populations may be good for long-term trends over large areas, but links to management may become unclear at these large scales. For a few species, relationships with particular forest elements or structures are sufficiently well documented that declines can, at least initially, be attributed to lack of that element. Management actions to increase supply of those attributes (e.g., downed wood, dead trees) or pattern (e.g., forest interior) should be undertaken.

Focusing modelling effort. Information on species' associations can help refine relationships to allow modelling over long time frames and large areas. For example, several fungi, bryophytes, vertebrates, and invertebrates are associated with downed wood, and information on species and decay classes they use could help improve habitat models. As the models increase in their predictive ability, they are better able to reveal preferred practices.

Focusing finer-scale monitoring. Occurrence information or population trend information may indicate productivity problems for some species, and reasons to investigate their natural history more closely. Studies on dispersal, resilience, or productivity may be warranted. Findings of such studies may suggest ways to improve limiting factors.

The preceding forms of feedback to management are broadly applicable to all species. More specific comments for species and groups of species are offered in the AMF.

\section{Summary}

The monitoring portion of the adaptive management program examining indicators discussed above must determine not only what variables to monitor and how to monitor them, but what comparisons are most important. Weyerhaeuser is interested in comparing different types (patch, dispersed, and mixed) and amounts (percent retained) of VR, comparing VR to other harvesting methods, and comparing VR to natural stands or to targets, based on species' requirements. Clearly, not all indicators of interest can be measured for all comparisons of interest. Our current challenge is to define which indicators will be measured for which comparisons. We are approaching that question by developing a matrix that will record which indicators will be measured for which comparisons (Table 3). Results of these discussions refining the monitoring program will be available in 2003.

\section{References}

Arcese, P. and A.R.E. Sinclair. 1997. The role of protected areas as ecological baselines. Journal of Wildlife Management 61: 587-602.

Arsenault, A. and T. Goward. 2001. Ecological characteristics of inland rainforests. In L. Darling (ed.). Proceedings of a conference in the biology and management of species and habitats at risk, Feb 15-19. pp. 759-766. UCC Kamloops, British Columbia.

Beese, W.J., B.J. Dunsworth, K. Zielke, and R. Bancroft. 2003. Maintaining attributes of old-growth forests in coastal B.C. through variable retention. The Forestry Chronicle 79(3): 570-578.

Beese, W. and K. Zielke. 1998. A forest management strategy for the $21^{\text {st }}$ century. Silviculture - a new balance. MacMillan Bloedel, Nanaimo, British Columbia.

Beier, P. and R. Noss. 1998. Do habitat corridors provide connectivity? Conservation Biology 12: 1241-1252.

Brown, E.R. (tech. ed.). 1985. Management of wildlife and fish habitats in forests of western Oregon and Washington. USDA Publ. No. R6-F\&WL-192-1985. 302 p.

Bunnell, F.L., L.L. Kremsater and M. Boylan. 1998. An ecological rationale for changing forest management on Macmillan Bloedel's forest tenure. Publication No. R-22, Centre for Applied Conservation Biology, University of British Columbia, Vancouver, British Columbia. Bunnell, F.L., L.L. Kremsater and E. Wind. 1999. Managing to sustain vertebrate richness in forests of the Pacific Northwest: relationships within stands. Environmental Reviews 7: 97-146.

Daniels, L.D., J. Dobry, K. Klinka and M.C. Feller. 1997. Determining year of death of logs and snags of Thuja plicata in southwestern coastal British Columbia. Canadian Journal of Forest Research 27: 1132-1141.

Harmon, M.E., J.F. Franklin, F.J. Swanson, P. Sollins, S.V. Gregory, J.D. Lattin, N.H. Anderson, S.P. Cline, N.G. Aumen, J.R. Sedell, G.W. Lienkaemper, K. Cromack Jr. and K.W. Cummins. 1986. Ecology of coarse woody debris in temperate ecosystems. Advances in Ecological Research 15: 133-302.

Lehmkuhl, J.F. and L.F. Ruggiero. 1991. Forest fragmentation in the Pacific Northwest and its potential effects on wildlife. In L.F. Ruggiero, K.B. Aubry, A.B. Carey and M.H. Huff (Tech. Coords.) Wildlife and vegetation of unmanaged Douglas-fir forests. pp. 35-46. USDA For. Serv. Gen. Tech. Rep. PNW-GTR-285.

MacArthur, R.H. and J.W. MacArthur. 1961. On bird species diversity. Ecology 42: 594-598.

Murcia, C. 1995. Edge effects in fragmented forests: implications for conservation. Tree 10: 58-62.

Mulder, B.S., B.R. Noon, T.A. Spies, M.G. Raphael, C.J. Palmer, A.R. Olsen, G.H. Reeves and H.H. Welsh. 1999. The strategy and design of the effectiveness monitoring program for the Northwest forest plan. USDA Forest Service, Gen. Tech. Rep. PNW-GTR-437. Niemela, J., Y. Haila and P. Punttila. 1996. The importance of small-scale heterogeneity in boreal forests: variation in diversity in forest floor invertebrates across the succession gradient. Ecography 19: $352-368$ 
Pojar, J., K. Klinka and D.V. Meidinger. 1987. Biogeoclimatic ecosystem classification in British Columbia. Forest Ecology and Management 22: 119-154.

Prezio, J.R., M.W. Lankester, R.A. Lautenschlager and F.W. Bell. 1999. Effects of alternative conifer release treatments on terrestrial gastropods in regenerating spruce plantations. Canadian Journal of Forest Research 29: 1141-1148.

Okland, B., A. Bakke, S. Hagvar and T. Kvamme. 1996. What factors influence the diversity of saproxylic beetles? A multiscale study from a spruce forest in southern Norway. Biodiversity and Conservation 5: 75-100.

Sætersdal, M. and H.J.B. Birks. 1993. Assessing the representativeness of nature reserves using multivariate analysis: vascular plants and breeding birds in deciduous forests, western Norway. Biological Conservation 65 : $121-132$.
Soulé, M.E. and M.A. Sanjayen. 1998. Conservation targets: do they help? Science 279: 2060-2061.

Stokland, J.N. 1997. Representativeness and efficiency of bird and insect conservation in Norwegian boreal forest reserves. Conservation Biology 11: 101-111.

Thomas, J.W. (ed.). 1979. Wildlife habitats in managed forest in the Blue Mountains of Oregon and Washington. US Department of Agriculture, Forest Service. Agriculture Handbook 553, Washington, DC. 